\section{Marine litter keeps increasing}

SIR - In addition to being aesthetically unappealing, litter has direct impacts on marine ecosystems. It provides novel attachment sites for sessile organisms, kills or injures animals that become entangled in or eat litter, and possibly aids dispersal of terrestrial organisms ${ }^{1}$. The amount of litter at sea is increasing despite control measures.

Floating litter drifts throughout the world's oceans, either dumped from ships or blown and washed from land. Even Antarctica, far from source areas, is affected ${ }^{2}$. Plastic articles pose the greatest problem: once at sea, plastics are virtually immune to degradation and can drift for years, covering vast distances. Steps taken to curb the release of persistent litter into the sea include education, product substitution and legislation. The most far-reaching step was taken in 1987, when countries responsible for more than half the world's shipping acceded to Annex $\mathrm{V}$ of the International Convention for the Prevention of Pollution from Ships (MARPOL), which bans the disposal of persistent wastes at sea $^{1}$. This measure came into force at the end of 1988 , but there have been few attempts to monitor its effectiveness.

Between 1984 and 1990, we surveyed litter washed up at Inaccessible Island $\left(37^{\circ} 15^{\prime} \mathrm{S}, 12^{\circ} 30^{\prime} \mathrm{W}\right)$, a remote island in the Tristan da Cunha group, south Atlantic Ocean ${ }^{3,4}$. The island is uninhabited and is seldom visited, making it ideal for monitoring the rate of litter accumulation. The figure shows how the density of litter increased exponentially throughout the study period, with MARPOL Annex $V$ having no discernible impact on the rate of increase. Plastic articles comprised more than $80 \%$ of the litter, with most identifiable items coming from South America, more than $3,000 \mathrm{~km}$ distant.

The exponential increase in marine litter throughout the latter half of the 1980 s contrasts with the amount of scientific research on the subject. Numbers of publications addressing the marine litter problem peaked in 1987 (see figure), coinciding with the decision bringing into force MARPOL Annex V. The recent decrease in publications may stem from a perception in some quarters that the threat posed by marine litter has been identified adequately, and that resources are better allocated to control measures than to research and monitoring. This viewpoint is simplistic. The impact of marine litter remains poorly understood. We know little about the effects of entanglement and ingestion on marine populations, and there has been no study of the consequences of greatly increasing habitat availability for sessile organisms in oceanic ecosystems. Until these questions are addressed, we cannot rank marine litter relative to other environmental problems, and thus cannot sensibly decide how much attention it war-

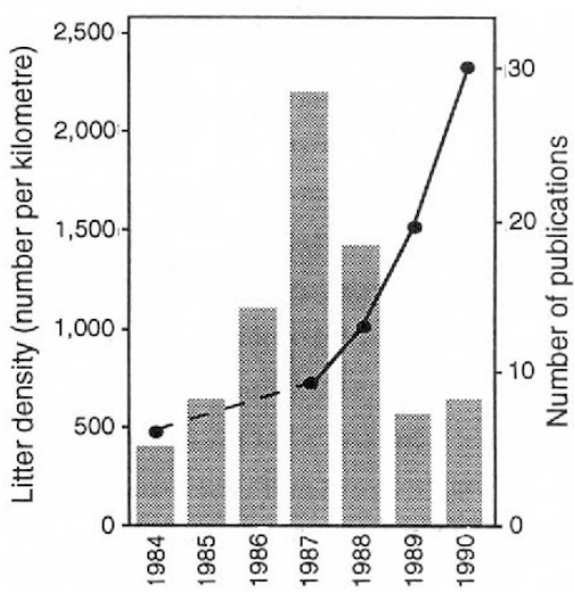

Increase in the amount of litter stranded on the west side of Inaccessible Island between 1984 and 1990 (plotted line $)^{2,3}$, and the number of publications on the marine litter problem in the primary scientific literature over the same period (histogram, based on a survey of 55 journals)

rants. Further research is required both to assess the impact of marine litter and to sustain efforts to curb its release.

\section{Peter G. Ryan}

Coleen L. Moloney

FitzPatrick Institute,

University of Cape Town,

Rondebosch 7700 .

South Africa

1. Shomura, R. S. \& Godfrey, M. L. (eds) Proc. 2nd int. Cont. Marine Debris, NOAA Tech. Mem. NMFS 154. 1-1274 (1990)

2. Gregory, M. R., Kirk, R. M. \& Mabin, M. C. G. N. Z Antarct. Rec. 7 (3), 32-47 (1984)

4. Ryan, P. G. Proc. 2nd int. Conf. Marine Debris, NOAA Tech. Mem. NMFS 154, 85-102 (1990).

\section{Ribosomal RNA trees misleading?}

SIR - Phylogenetic placing of protozoa that lack mitochondria is crucial in clarifying the early evolution of eukaryotes ${ }^{1}$. Most studies relevant to this problem have been done using small-subunit ribosomal RNA (ss rRNA) sequences ${ }^{2-4}$. These studies suggest that, among three protozoa lacking mitochondria, Giardia lamblia and Vairimorpha necatrix represent the earliest and the second earliest offshoots in the eukaryotic tree, whereas Entamoeba histolytica separated from higher eukaryotes after Euglena gracilis and Trypanosoma brucei (both with
3. Ryan, P. G. Envir. Conserv. 14, 341-346 (1987). mitochondria) diverged. However, we suggested $^{5-7}$ that this tree could be erroneous because $\mathrm{G}+\mathrm{C}$ content of ss rRNA differs drastically among species, and because this effect has not been taken into account in inferring the ss rRNA tree. For example, the $\mathrm{G}+\mathrm{C}$ content of $G$. lamblia is as high as $74.7 \%$, while those of $V$. necatrix and $E$. histolytica are as low as 37.7 and $38.3 \%$.

From a maximum likelihood ${ }^{8,9}$ analysis of amino-acid sequence data of elongation factor $1 \alpha$, we have now shown ${ }^{5}$ that $E$. histolytica is likely to be an outgroup to $E$. gracilis and higher eukaryotes, in disagreement with the ss rRNA tree. Furthermore, from a parsimony analysis of amino-acid sequence data of DNA-dependent RNA polymerase III, Lanzendörfer et al. ${ }^{10}$ suggested that $G$. lamblia may not be an outgroup to $T$. brucei and higher eukaryotes, again in disagreement with the ss rRNA tree. Although statistically inconclusive, we reconfirmed ${ }^{6}$ their suggestion by using the maximum likelihood method.

We have further shown that the amino-acid compositions of these highly conservative proteins are relatively free from the variation of biased base compositions of DNA and ss rRNAs (refs $6,7)$. From these results, we suggest that the ss rRNA tree representing early branchings of eukaryotes must be reexamined by using amino-acid sequences of conservative proteins such as elongation factors, RNA polymerases and ATPases. The ss rRNA sequences have been widely used in clarifying deep branchings in phylogenetics, and they have provided us with invaluable information. Nevertheless, we must be careful in using these data, particularly when the $\mathrm{G}+\mathrm{C}$ content differs among species $^{11}$.

\section{Masami Hasegawa}

Tetsuo Hashimoto

Institute of Statistical Mathematics,

4-6-7 Minami-Azabu,

Minato-ku,

Tokyo 106

Japan

1. Cavalier-Smith. T. Nature 339, 100-101 (1989)

2. Vossbrinck, C. R. et al. Nature 326, 411-414 (1987)

3. Sogin. M. L. et al. Science 243, 75-77 (1989).

4. Sogin, M. L. Curr. Opin. genet. Dev. 1, 457-463 (1991).

5. Hasegawa, M., Hashimoto, T., Adachi, J., Iwabe, N. \& Miyata, T. J. molec. Evol. (in the press).

6. Hashimoto, T. Adachi, J \& Hasegawa, M Endocytobiosis Cell Res. (in the press).

7. Hasegawa, M., Hashimoto, T. \& Adachi, J. in The Origin and Evolution of Prokaryotic and Eukaryotic Cell (ed. Hartman, H. \& Matsuno, K.) (World Sci. Publ., in the press).

8. Kishino, H., Miyata, T. \& Hasegawa, M. J. molec. Evol 31, 151-160 (1990).

9. Adachi, J. \& Hasegawa, M. MOLPHY: Programs for Molecular Phylogenetics, 1. - PROTML: Maximum Likelihood Inference of Protein Phylogeny (Institute of Statistical Mathematics, Tokyo, 1992)

10. Lanzendörfer, M. et al. Nucleic Acids Res. 20, 1145 (1992).

11. Loomis, W. F. \& Smith, D. W. Proc. natn. Acad. Sci. U.S.A. 87, 9093-9097 (1990) 